\title{
BELLIGERENT OCCUPATION AND THE GENEVA PROTOCOL, 1977: A SWEDISH PERSPECTIVE
}

\author{
JACob SundberG* \\ I \\ General Issues
}

\section{A. Defense Planning and Foreign Policy}

In his report to the Swedish Academy of War Sciences ${ }^{1}$ in 1972, I. Müller touched upon the issue of guerrilla wars waged by the civilian population: "In Sweden we reckon with the fact that irregular war will be conducted behind enemy lines, and it seems very likely that resistance movements will someday form among us behind enemy lines, inter alia, in support of irregular war. ... In view of these facts, Swedish foreign policy is working vigorously to create further rules of international law for the protection of the civilian population."2

In July, 1977, after the adoption in Geneva of the Protocol Additional to the Geneva Convention of August 12, 1949, and Relating to the Protection of Victims of International Armed Conflicts (Protocol 1), the Swedish Foreign Office put out a pamphlet surveying what the Convention had accomplished. This pamphlet bears out, in part, what Müller had suggested. It relates:

In the conference work the Swedish delegation was certainly one of the most energetic on many questions and exercised considerable influence on the final result ... Swedish delegates were also very active in negotiating the rules for the protection of civil defense. On certain other central points, other small states were particularly influential (for example, Norway, concerning the protection of guerrilla soldiers). ${ }^{3}$

\section{B. Air Warfare Versus Guerrilla Warfare-Shifting the Scales}

Protection of the civilian population under belligerent occupation, which may have been a central theme in Swedish planning, was only of marginal interest at the Red Cross conferences that eventually produced the Geneva Protocols. The Geneva Protocols, essentially the result of the confrontation be-

\footnotetext{
* Professor of Jurisprudence, University of Stockholm.

1. Kungl. Krigsvetenskapsakademin (author's translation). Unless otherwise specified, translations from original are by author-Ed.

2. Müller, Civilförsvaret och säkerhetspolitiken, 1972 KKVA HandLINGAR OCH TIdSKRIFt 165.

3. UD informerar-Krigets lagar-Manskliga rättigheter i väpnade konflikter-1977:4, at 5 .
} 
tween two modes of combat that had until then been largely neglected in international law--air warfare and guerrilla warfare-had a different focus. Combat aircraft were hardly taken seriously among the draftsmen at The Hague in 1907 when the basic rules of warfare were hammered out. Even though a prohibition of discrimination based on "wealth" was introduced into article 3 of the Red Cross Conventions of 1949, most of the delegates in Geneva in 1949 did not appreciate that guerrilla warfare was the apex of the Marxist class struggle, nor did the experts on the matter find reason to lecture on it. In the Vietnam war, however, the struggle was, in a most clear-cut fashion, between one side relying on guerrilla warfare and the other side relying on air warfare. The work leading to the adoption of the Geneva Protocols was in many respects an attempt to interfere with the Vietnam war by shifting the scales in favor of the guerrillas, at the expense of the air combatants.

During this period, the period of the Vietnam war, Sweden was pursuing a foreign policy that made the country an Albania to America and the Western industrialized nations. This policy led to the withdrawal of the American Ambassador from Sweden. It was therefore natural that Sweden should participate energetically in the Red Cross conferences. Now that the Vietnam war is over, the Vietnamese borders are shut tight, and the Geneva Protocols are adopted, it may be an appropriate time to relate the Protocols that resulted from the conference to the image of Swedish territory under belligerent occupation that was on the minds of some of those originally endorsing this great diplomatic campaign.

\section{A Peculiar Kind of Criminal Law: The Law of War}

When dealing with the law of war, one often loses sight of the fact that this body of law is essentially disciplinary law for the armed forces; this function entails all the problems of criminal law. For these reasons, it is useful to look for a moment at the relationship between criminal law and international law.

Bassiouni has provided a thoughtful analysis of international criminal law, characterizing it as "a product of the convergence of the international aspects of municipal criminal law." ${ }^{4}$ Bassiouni maintains that "[s]uch doctrinal divergencies which exist between international law and criminal law gave international criminal law a 'split personality' which has plagued its development." This split personality is not a happy one. As B. J. George has written, "[N]othing other than an awareness of prevalent human misconduct seems to bind together those who concern themselves professionally with criminal law

4. Bassiouni, An Appraisal of the Growth and Developing Trends of International Criminal Law, 46 ReVUe INTERNATIONALE DE DROIT PENAL 405, 406 (1975).

5. Id. at 426 . 
and procedure. Each country's code tends to be viewed as a self-contained body of law bearing no relationship whatever to the law in any other country." ${ }^{6}$ On the other hand, Gerhard Mueller has remarked, "A municipal criminal lawyer cannot but with a certain admiration and astonishment look the extraordinary enthusiasm of those international lawyers who have been primarily responsible for this new peace-insurance machinery which simply rests on the creation of a code and an international court." 7 To Mueller, this code-the U.N. Draft Code on Offences Against the Peace and Security of Mankind-“reveals an almost reckless abandonment of all concern for those principles which mankind has learned to appreciate as essential for the effectiveness of criminal law."

Against this background, it is interesting to note that among the driving forces that led to the formulation of the Protocols at the Red Cross conferences there was, at times, little understanding that extending prisoner of war status to the guerrillas meant intruding upon those chapters of the penal codes that deal with crimes of lèse-majesté and the like. ${ }^{9}$ One might ask just how many of those attending the conferences fully understood what was actually being achieved.

For these reasons, perhaps we should not accept the international law created in this field at face value but instead review it critically. Since Swedish interest in the matter turned on the law of belligerent occupation, it seems appropriate to make this the focus of our interest. Our main concern will be to see to what extent the present formulations of the international law are relevant to genuine Swedish interests. We will also examine certain factors that seem to make some of these formulations altogether irrelevant.

\section{The Norwegian Model and its Limits}

Recent Swedish thinking devoted to belligerent occupation has been based largely on a Norwegian model. ${ }^{10}$ This model may be described as the case of the "grand attack." The great power attacks from overseas; the Swedish government puts up a fight but ultimately has to find refuge in some allied coun-

6. George, Foreword to 15 WAyne L. Rev, 607 (1969).

7. Mueller, The United Nations Draft Code on Offences Against the Peace and Security of Mankind: An American Evaluation, in G. Mueller \& E. Wise, International Criminal Law 597, 611 (1965). See also Draft Code of Offenses against the Peace and Security of Mankind, 9 U.N. GAOR, Supp. (No. 9), U.N. Doc. A/2693 (1954).

8. Mueller, supra note 7 at 616 .

9. Evidently, the head of the Swedish delegation, Dr. Hans Blix (now Minister of Foreign Affairs), was not fully conversant with the criminal law implications, judging from the discussion that followed his lecture, Should the Laws of War be Modernized?, given at the Faculty of Law in Stockholm (October 10,1972).

10. When drafting the new Swedish Constitution of 1974, the Norwegian wartime experience was the only one relied upon. See Statens offentliga utredningar 1972:18 (Norway and the Norwegian Government-in-Exile During the Second World War). 
try overseas; a resistance movement is created; resistance is offered in every situation; and finally victory comes when the government returns with its victorious allies. The famous pamphlet, Om kriget kommer (If War Comes), relied on this model. First published in 1943, Om kriget kommer was heavily influenced by the misfortunes of the Norwegians and the roots of their troubles. The pamphlet gave vent to the tough approach of the wartime years, which continued throughout the nervous 1950s. "Resistance shall be made always and in every situation," it declared. "We will never give up. Every announcement that resistance is to be abandoned is false."11

Today, however, one might doubt whether the Norwegian model is realistic. Certain conditions had to be satisfied before the Norwegian resistance movement was even accepted as a national movement. In 1956 the holders of the three Swedish chairs of international law published a report called The Norwegian Purge, ${ }^{12}$ which looked into the historical development of the movement more closely. The professors strongly emphasized the importance of the rapidly increasing antagonism between Germany and Russia in 1941, which ultimately resulted in the outbreak of war in June of the same year. The German attack on the Soviet Union, drawing the Communists into the fight against Germany, created the necessary prerequisites for Norwegian unity. ${ }^{13}$ There is no reason to expect a similar development of unity if Sweden became involved in a war: no matter how Sweden might be drawn into a war, we can expect pro-West or pro-East guerrilla activity. The Norwegian model is deceptive from the outset.

This becomes even more clear if one considers the development in Sweden described by foreign observers as "finlandization," which has been brewing in Sweden since the mid-sixties. This observation of "neutralization and exposure to Soviet threats"14 refers basically to the combination of Sweden's bor-

11. The pamphlet was first published, pursuant to Royal order, by Statens informationsstyrelse in 1943. A second edition, by Civilförsvarsstyrelsen, appeared in 1952; the third and last edition was put out by the Department of the Interior in 1961.

12. H. Eek, E. Fahlbeck \& H. Sundberg, Den NORSka RätTSUPPGörelsen-Responsum och UTREDNING (Institutet för offentlig och internationell rätt $\mathrm{nr}$. 18).

13. "When the period of resistance may be said to have come into being is hard to say but in the Report, on the basis of Norwegian sources, the change in attitude is believed to coincide with the entry into war of the Soviet Union, the Norwegian communists turning from Germanophiles to Germanophobes, turning to sabotage and violent attacks as means of combat, and the shift in the fortunes of war, the Germans starting to suffer military setbacks that gave hope to the Norwegians. It would seem that not until 1943 did the Home Front and the London Government accept violence as a means of struggle; the arrest of the Norwegian officers followed the same year, removing them as prisoners of war to camps in Germany and simultaneously Sweden announced the termination of the transit traffic." $H$. Sundberg, Den norska rätsuppgörelsen och svenska medborgare, 1958 Förvaltningsrättslig tidskrift 192. Compare R. Petrow, The Bitter Years: The Invasion and Occupation of Denmark and Norway, April 1940-May 1945 (1974).

14. Sulzberger, To the Finland Station?, N.Y. Times, June 18, 1972, \& 4, at 15, col. 1. David Vital refers to "the now traditional and well-understood forms of loose and indirect control over Finnish affairs;" and, in contrast, the tendency "to manipulate-or manoeuvre within-a balance 
der state location and its increasing alienation of the power that can counterbalance the hegemonial power. The insidious effects of finlandization on Sweden's fighting spirit make a repetition of the Norwegian type of national consensus highly unlikely.

\section{E. The Law of Belligerent Occupation}

A few centuries after the end of the religious wars, European wars came to be waged between soldiers representing states that employed them, rather than between peoples. A parallel development in military thinking established the occupation of enemy territory as the ultimate end of army operations. In the wake of these developments, efforts devoted to formulating the laws of war during the time of the Concert of Europe focused largely on belligerent occupation. This work resulted in the Hague Rules of Land Warfare. ${ }^{15}$

After the end of the Second World War, an attempt was made to develop further the principles of the Hague Rules. The 1949 Red Cross Conventions resulted from these endeavors. The Fourth Convention, the Geneva Convention relative to the Protection of Civilian Persons in Time of War of August 12, 1949, contains a number of rules for the relationship between the occupying power and the inhabitants of the occupied territory. The Third Convention, the Geneva Convention relative to the Treatment of Prisoners of War of August 12, 1949, is also often applicable in situations arising under occupation.

Like its Scandinavian neighbors Denmark and Norway, Sweden has ratified the Hague Convention of 1907 with the Rules of Land Warfare. When the Red Cross Conventions were signed, a meeting of Ministers in Oslo in March, 1951, decided that experts should discuss problems of interpretation before ratification was undertaken. A Committee was set up for that purpose: "de skandinaviske utvalg av sakkyndige til fortolkning av visse bestemmelser i Genevekonvensjonene."16 Among the Committee's members were Professor Castberg and Mr. Justice Kruse-Jensen from Norway, Profes-

\footnotetext{
of restraint and pressure between it and the preponderant power in whose sphere it falls." D. VItal, The Survival of Small States 115, 117 (1971).

15. Hague Convention No. IV respecting the Laws and Customs of War on Land, October 18, 1907, Regulations Annexed, [1910] 36 Stat. 2277, T.S. No. 539, 2 Malloy, Treaties 2269, containing a master pattern for the instructions to be issued to the armies of the warring parties to the Convention [hereinafter referred to as the Hague Rules; all references to this source are to The Hague Conventions and Declarations of 1899 and 1907 (J. Scott ed. 1915)]. A number of articles of this Annex refer to the relationship between the occupying power and the inhabitants of the occupied territory.

16. The story of the committee is reported in Rapport fra de skandinaviske utvalg av sakkyndige til fortolkning av visse bestemmelser i Genève-konvensjonene. Manuscript No. 151-1. The title page of this publication explains, "This is not to be considered as a rule book [reglement] and does not contain provisions of a rule character [reglementeriske bestemmelser]. It is printed by the Supreme Army Command rather than being mimeographed and will be distributed in the Army for information purposes." (Author's translation.)
} 
sor Gihl of Sweden, and Minister Georg Cohn of Denmark. On October 1, 1952, the committee's report was ready. The Norwegian Supreme Army Command (Haerens Over Kommando) published the report later in 1952. By that time, Denmark and Norway had already deposited their instruments of ratification of the two Conventions-Denmark, on June 27, 1951, and Norway, on August 3, 1951. Only Sweden awaited the publication of the report before ratifying on December 4 , 1952. The rules of the Geneva Protocols are superimposed on this body of law.

We have yet to characterize the law developed in the 1949 Red Cross Conventions and the Hague Conventions of 1907. This body of law, ultimately derived from late nineteenth-century military thought, displays a markedly bourgeois view of war and law. From its perspective, war is decidedly a confrontation between states and their armed forces; war is a duel between states, a contest that may, like the duel, still be tied to certain forms in pursuance of certain goals-whatever the bloodshed. By and large, all governments are fundamentally the same and differ only in details; war, even if it cannot be avoided altogether, is in essence a regrettable interruption of the normal order within an otherwise harmonious civilization. Since war is a contest between states, it shall also, so far as possible, be limited to the states; as a result, private property is inviolable. Just as no individual state is entitled to violate the private property of its inhabitants, neither can an enemy state violate the private property of inhabitants in territory it occupies as part of its war against the inhabitants' former state. Finally, the idea that judicial review is the safeguard against abuse prevails in this body of law; the court is there to protect the individual against the state, and consequently it is up to the courts to see that the state does not overstep its competence.

F. The Law in Action: Bourgeois States and Socialist States

Belligerent occupation has occurred from time to time in the course of the many wars, big and small, that have taken place during this century. The conditions of the 1940s, when the German Reich came overseas and occupied Norway, are, of course, those closest to Swedish experience. In this case, a power of socialistic philosophy (albeit "National" Socialism) occupied a power of bourgeois philosophy. This creates some tension for analysis from the perspective of the law of war: the ideology of the occupying power was in many ways in conflict with the philosophy of the Hague Rules insofar as they related to belligerent occupation, in particular, with regard to the inviolability of private property and the necessity of judicial review. The predominant view in Germany at that time went against setting up any laws for the administration. Such antipathy is not exceptional: Mr. Justice Wennergren characterizes modern Swedish administration as follows: "In many fields the activity of the authorities . . . is dominated by informal relationships or negotiations and 
contracts." ${ }^{17}$ But the Germans went much further. Courts had absolutely no jurisdiction in public administration: "Es dürfen über Führungsfragen nicht Nicht-Führer entscheiden [only those who are leaders are to decide leadership questions]." ${ }^{18}$ Expanding the political administration and releasing it from legal form was the precondition for putting people into concentration camps for indeterminate periods and making "the people's sense of justice, such as we find it in genuine popular feeling" (Volksempfinden) the basis for sentencing people. ${ }^{19}$ On the other hand, within the occupied state, with Norway's emotional fixation on the Eidsvoll Constitution and constitutionalism in general, the view of law generally taken at that time was very much in harmony with the leading ideas of the Hague Rules.

It is well known that the debellatio the German Reich suffered in 1945 is supposed to have prevented the applicability of the law of belligerent occupation in its case. But debellatio also has a place in Marxist legal thinking.

Marxist thinking is deterministic. The developing process leads inexorably upwards: it cannot go downwards or turn in circles. Consequently, it leads inevitably from capitalism to socialism; it cannot lead from socialism to capitalism. If such a perversion threatens to take place, all good forces are called upon to prevent it and set the development back on the right course, as the world has been reminded from time to time-the last occasion being when the so-called Brezhnev Doctrine explained why the Czech Spring of 1968 could not continue. Essentially, we are faced with a belief in the predetermined advance of civilization and in an overriding legal duty to prepare and assist in this process-when necessary, by resort to armed force.

It is fully consonant with this thinking that when the Soviets occupied Polish territory pursuant to the Ribbentrop Pact of 1939, the People's Commissariat for Foreign Affairs, in an official note of September 17, 1939, should proclaim, as a basic "theoretical conception," the "nonexistence" of the Polish bourgeois state. ${ }^{20}$ In keeping with this class struggle "debellatio," the Polish

17. WENNERGREN, SVENSK JURISTTIDNING 558 (1951).

18. TATARIN-TAMHEYdEN, 1934 ARChiv deS ÖFFENTlichen ReChts 356 (editor's translation).

19. This is the infamous general clause in Section 2 of the 1871 German Penal Code (Reichsstrafgesetzbuch), as amended on June 28, 1935. Cf. Hamburger, L'analogie dans le drout pénal allemand, 1937 RevUe dE SCIENCE CRIMINELLE ET DE DROIT PÉNAL COMPARÉ 182-194.

20. It should be noted that the German prisoners of war in the Soviet Union were sentenced in a similar way-see generally $R$. Maurach, Die Kriegsverbrecherprozesse gegen deutsche Gefangene in Der Sowjetunion 14 (1950)-although the expectations of its allies forced the Soviet Union to a certain amount of adaptation to the classical international law rather than pursuing its socialist theory of war: "Der Krieg ist für die Sowjetideologie eine zwangsläufige Begleiterscheinung der kapitalistich-imperialistischen Ordnung, sei es, dass Staaten dieser Struktur miteinander in Konflikt geraten, sei es, das die bewaffnete Auseinandersetzung ihr wahres Gesicht offenbart, nämlich den offenen Kampf zwischen den rivalisierenden Klassen, den globalen Burgerkrieg, der seinem Wesen nach nie mit einem Kompromiss, sondern nur mit den Sturz und der Totalvernichtung [ergo, debellatio] eines der ringenden Systeme enden kann." 
armed forces enjoyed no protection under the Hague Rules or the $1925 \mathrm{Ge}$ neva Convention and were simply "members of armed bands" resisting legal authority and were to be treated according to the criminal law. This paved the way to the woods of Katyn. ${ }^{21}$

There seems to be no reason to suppose that such thinking will not be prolonged into the future. Even among the victorious Western powers of the Second World War, the will to respect the Hague Rules failed when debellatio was the ultimate goal. "The truth is," wrote the British professor of international law, H. A. Smith, "that from the first it was part of [the Western powers'] avowed military purpose to destroy utterly the two totalitarian systems. They had announced in advance their intention of doing precisely what the Hague Rules had purported to forbid, except that they 'respected' and continued in force the normal civil and penal codes." 22 A similar destructive intention must, of course, be present when a socialist power overcomes a social order that it conceives as being bourgeois-in socialist thinking, this state is doomed to die anyway, and it is totally evil and offensive to public morals because it is imperialistic and war provoking. The difference between the imperialism of the Western powers and Nazi imperialism is minimal in this respect, compared to the difference between the principles followed in the socialist camp and those embodied in the capitalist social order.

How the regulation of belligerent occupation will function when a socialist state occupies another socialist state, and whether the resultant views of the states will fail to remain in harmony with the perspective of the Hague Rules, is still pure speculation. But when Sweden discusses belligerent occupation, this issue is the heart of the matter.

Social development in Sweden has long advanced into a purer kind of socialist system-a development moving at an accelerated pace since the midsixties-partly by means of the tax system, which has brought about what is hereinafter referred to as the "high tax society," and partly because of a new view of courts and the judicial function. The Swedish tax system, which has long been steeply progressive, has been employed for a number of other purposes besides providing revenue for the state. Its use as an instrument of economic policy is now commonplace. Tax rebates are devised to provide incentives for a certain type of enterprise, or a certain region, or a certain group of people. The levelling effects on the economic conditions of the citizens are seen as one of the central tasks of the tax system. The tax system is a new, enormous, and all-pervading power apparatus.

The Swedish courts have become increasingly politicized. This began when the lay assessors became politically elected officials after the Second World

21. I have relied here on the collection of documents published by Fitzgibbon. L. FitzGibBon, The Katyn Massacre 34 (1977).

22. Smith, Book Review, 7 InT'L \& CoMp. L. Q. 789, 792 (1958). 
War. Thereupon the lay assessors were given increased influence upon court judgments. Eventually the lay assessors' service on the bench was regarded as a special political responsibility. This role was explained in Parliament when the so-called lex Timrå was passed: "To us, Social Democrats, it can never be a question of the responsibility for the political ideology . . . disappearing if we are elected lay assessors." ${ }^{23}$ Similarly, the attitude towards judicial office was much less unequivocal and high-principled in the new Constitution of 1974 than it had been previously. "The new Constitution completely discards the separation-of-powers system that characterized, originally, the 1809 Constitution"; "the fact that the separation-of-powers principle thereby disappears is an important advance in my view and an essential part of the reform," explained the Swedish Minister of Justice. ${ }^{24}$ One may also trace the development of a new attitude among Swedish judges. In a doctoral dissertation published in 1973, Frändberg asserted, "In Sweden, there is no doubt that the judicial organs consider themselves subordinate to the highest political organs (Parliament and Cabinet) ... . although these [judicial organs] under the [1809] Constitution are equal to the former [political] organs and furthermore nowadays have a law-making function that has clearly been spelled out."25

The Swedish society in which an application of the rules of belligerent occupation should be envisaged is consequently not of the same kind as the Norwegian society upon which the German occupation was imposed; it is even less similar to the bourgeois society under the rule of law that was in the minds of the drafters of the Hague Rules.

\section{II}

\section{The Case Study}

\section{A. The Administration of Occupied Territory}

The 1949 Red Cross Conventions set up a rather detailed model for the administration of occupied territory. If we apply this pattern to a hypothetical Swedish situation, the following picture emerges.

From article 64 of the Fourth Convention, ${ }^{26}$ it follows that within Sweden as an occupied territory the domestic Swedish legal order and court organization would be left to operate as before, though with some exceptions.

The Swedish legal order would be supplemented by a new system of pro-

23. Snabbprotokoll från riksdagsdebatterna $1975 / 1976 \mathrm{nr} .45$, at 13 passim. The Act that is called lex Timrå reacted against the socialist parties in Timrå that had made a point of making only socialists lay assessors.

24. Kungl. proposition 1973:90, at 91, 155. Cf. Statens Offentliga Utredningar 1974:15, at 76.

25. FrändBerg, OM analog aVÄNDNing av rätTSNORMER 159 (1973).

26. Geneva Convention relative to the Protection of Civilian Persons in Time of War of August 12, 1949, 6 U.S.T. 3516, T.I.A.S. No. 3365, 75 U.N.T.S. 287 [hereinafter referred to as the Fourth Convention]. 
visions aimed at maintaining orderly government and ensuring the security of the occupying forces. These provisions are to be enforced through powers bestowed upon the occupying power by article 64, paragraph $2,{ }^{27}$ and are to be issued by the enemy commander in the area. This commander would be subject to the requirements set out in article 65 to the effect that the penal provisions shall not come into force before they have been published and brought to the knowledge of the inhabitants in Swedish; their effect may not be retroactive. Thus, the commander would hold the powers of government: all administrative and legislative powers would be in his hands. Violations of his ordinances and criminal acts against the security of the occupying power would be tried in his military courts, pursuant to article 66 . These courts must be properly constituted, they must sit in the occupied territory, and they may not be political. Apparently, the Civilian Convention assumes, without stating so explicitly, that the courts of the expelled power would be nonpolitical一an assumption that would not hold true in a socialist country.

According to article 54, the occupying power may not change the status of public officials or judges yet is always empowered to remove them from their posts. The powers of the enemy commander include employing public officials such as judges and policemen.

It seems likely, then, that the local Swedish courts would carry on as before and would be recruited from the local Swedish population. The political elections of lay assessors, however, would create a problem. One could hardly expect that the occupying power would not influence such elections in favor of its sympathizers - for example, by prohibiting other political activity. The end result may well be that the local courts will be political, while the military courts will not.

In the Hague Rules it is assumed that the local police force will consist of the same personnel that served before the occupation. By the Swedish Act of 1943, relating to the status of the police in time of war, it was decided that the police should have the same status under international law as that applied pursuant to the Hague Rules to the armed military units participating in the hostilities. Provisions implementing this decision were enacted in 1958. The 1977 Geneva Protocols provide on this point, that a party who thus "incorporates a paramilitary of armed law enforcement agency into its armed forces .. . shall so notify the other parties to the conflict." 28 To the extent that this means that the local police will be made prisoners of war, apparently, the enemy commander will appoint his own policemen-or militia, as he may prefer to call them.

27. Id. at para. 2.

28. Int'l Comm. of the Red Cross, Protocols Addtional. to the Geneva Conventions of 12 August 1949, Protocol I, art. 43, para. 3 (1977). 
B. Focus on the Motor Repair Service (MRT)

To better understand the working of the system of law created for belligerent occupation by the treaty apparatus a case study is useful. Faced with a country of socialist philosophy like Sweden organized for war in a spirit of total defense, it seems appropriate to select one of the total defense organizations as the focus of study. We will therefore limit our further investigation to one important area of total defense, motor repairs-specifically, to the Motor Repair Service (MRT). This apparatus would require most repair shops in the country to serve the armed forces in a total defense effort. The shops would be staffed by a work force of civilians over age, normally those who were working there in time of peace. However, the executive level would be staffed by conscript officers or volunteers holding military rank from ensign to colonel.

\section{The Rights of the Occupying Power}

The system laid down in the Hague Rules, supplemented by the 1949 Red Cross Conventions and, on limited points, by the 1977 Geneva Protocols, gives the occupying power, besides its possibilities of ordering prisoners of war to work, three additional means of securing goods and services from the occupied country: making requisition, exacting contribution, and seizure.

Ordering prisoners of war to work is regulated by article 49 of the Third Geneva Convention. ${ }^{29}$ Requisition is regulated by article 52 in the Hague Rules and is characterized, above all, by the obligation to pay full compensation when private ownership is violated. Contribution, regulated in articles 48 and 49 of the Hague Rules, is characterized by the occupying power levying a tax "in accordance with the rules of assessment and incidence in force" at the time, ${ }^{30}$ that is to say, without compensation. Seizure is regulated in article $\mathbf{5 3}$ of the Hague Rules and is characterized by the occupying power's taking possession of the property in order to deprive the adverse party from benefiting therefrom; there is no compensation until after the end of the war.

\section{The Law in Action}

It may be expected that the occupying power would seize most materials operated by the MRT as being "all kinds of munitions of war" or "appliances ... adapted for the transmission of news, or for the transport of persons or things." 31 No compensation would be given, though the question of compensation would be

29. Geneva Convention relative to the Treatment of Prisoners of War of August 12 , 1949, 6 U.S.T. 3316, T.I.A.S. No. 3364, 75 U.N.T.S. 135 [hereinafter referred to as the Third Convention].

30. Hague Rules, supra note 15 , at art. 48.

31. Id. at art. 53 (italics indicate difference from Convention of 1899). 
discussed after the end of the war. The military personnel of the MRT would be treated as prisoners of war and would thus be liable to be used as labor within the framework of article 49 of the Prisoner of War Convention. Insofar as civilian personnel are concerned, the occupying power may requisition their services pursuant to article 52 of the Hague Rules. These services would be remunerated, presumably along the same lines as their work for the Swedish total defense.

Consequently, prima facie, the treaty regulation means that the complete MRT apparatus would be at the service of the occupying power. This does not mean, however, that the organization would be unconditionally at the disposal of the occupying power. There are also a number of restraints that may be invoked against the occupying power.

\section{E. The Officer Privilege}

Article 49 of the Prisoner of War Convention reads as follows:

The Detaining Power may utilize the labour of prisoners of war who are physically fit, taking into account their age, sex, rank and physical aptitude, and with a view particularly to maintaining them in a good state of physical and mental health.

Non-commissioned officers who are prisoners of war shall only be required to do supervisory work. Those not so required may ask for other suitable work which shall, so far as possible, be found for them.

If officers or persons of equivalent status ask for suitable work, it shall be found for them, so far as possible, but they may in no circumstance be compelled to work. ${ }^{32}$

Thus, it follows that "officers" are not under obligation to work. In the 1972 Swedish manual on how one is to act when taken prisoner of war, article 49 is rephrased as meaning that "officers and persons of equivalent status may only be given work that has been voluntarily consented to, and non-commissioned officers [plutonsofficerare] may only be used for supervisory work." ${ }^{33}$ The Articles of War in the Swedish Penal Code try to build character by adding that anyone who "procures for the enemy military manpower, equipment, provisions or support" may subsequently be sentenced for treason if the act "involves considerable aid to the enemy."34

However, in practice, the officer privilege has been easy to circumvent. During the Second World War, as part of intelligence operations in Britain, the German Unteroffiziere taken prisoners of war were simply deprived of their identity cards. Since these were never returned to their owners, the offi-

32. Third Convention, supra note 29 , at art. 49.

33. Krigsfånge-Anvisningarr för uppträdande i krigsfångenskap. 1972 års upplaga, fastställd av ÖB, at 67 .

34. The Penal Code of Sweden (T. Sellin trans. 1965), at ch. 22, $\S 1$ [hereinafter cited as 1962 Swedish Penal Code]. 
cers were unable to prove their status. In this way, 26,000 German noncommissioned officers were forced to perform prisoner of war service in the United States. ${ }^{35}$ The Scandinavian Report voices some skepticism in relation to issuing identity cards to the merchant fleet personnel and adds that the possession of the card is only a formality; ${ }^{36}$ but that hardly takes proper account of the practical situation, it would seem, considering the German experience.

\section{F. Military Operations Against One's Own Country}

Neither prisoners of war nor civilian personnel whose services are subject to requisition can be called upon to take part in military operations against their own country. However, it is necessary to distinguish between requisitioned services and prisoner of war work.

In article 52 of the Hague Rules it is said that the requisitioned services "shall be ... of such a nature as not to involve the inhabitants in the obligation of taking part in military operations against their own country." This connects with article 23, paragraph $h$, which forbids an occupying power to "compel the nationals of the hostile party to take part in the operations of war directed against their own country, even if they were in the belligerent's service before the commencement of the war." ${ }^{37}$ Article 51 of the Civilian Convention adds to this:

Protected persons may not be compelled to undertake any work which would involve them in the obligation of taking part in military operations. The Occupying Power may not compel protected persons to employ forcible means to ensure the security of the installations where they are performing compulsory labour. ... .

In no case shall requisition of labour lead to the mobilization of workers in an organization of a military or semi-military character, ${ }^{38}$

The meaning of this restraint (stop rule) is not fully clear. The Norwegian coastal trade's shipping of arms and ammunitions for the German Wehrmacht during the German occupation raised this issue. The Norwegian side argued that the Germans "were not entitled to force the inhabitants of the occupied country to render transportation services in the line of fire" and questioned whether service on a Norwegian coaster "should not be considered as transport service in the line of fire under conditions of land warfare." Certainly, transportation services outside the Norwegian territorial sea could not be requisitioned..$^{39}$

35. I Int'l Comm. of the Red Cross, Report of the International Committee of the Red Cross on Its Activitifs During the Second World War 339 (1948).

36. Rapport fra de skandinaviske utvalg, 1952, anm 10-Utferdigelse av identitetskort i henhold til krigsfangekonvensjonens art. 17, tredje ledd.

37. Hague Rules, supra note 15 , at art. $52 \&$ art. 23 , para. h (italics indicate difference from Convention of 1899).

38. Fourth Convention, supra note 26, at art. 51 .

39. F. CAstberG, Norge UNDer OKKUPASIONEN-RETTSLige UTREDNINGer 1940-1943, at 196 (1945). 
The introduction of the notions of "an organization of a military or semimilitary character" is not very helpful when confronted with the total-defense concept of society. Pictet's commentary leaves the matter with the following remark: "The application of this clause depends very largely on the good faith of the occupant, who must judge in each individual case, with a full sense of his responsibility in the matter whether or not the work demanded is compatible with the conditions here laid down." 40 The Scandinavian Report is perhaps more helpful. It says:

There was, however, a consensus that the occupying power cannot request the persons belonging to the civilian population of the occupied country to perform work that, since it is performed in the vicinity of the theatre of operations or due to other reasons, will expose those who are to perform the work to extraordinary danger [saerlig fare].11

As far as prisoners of war are concerned, the stop rule has received a very special formulation. Article 50 of the Prisoner of War Convention enumerates those categories of work that prisoners of war may be ordered to perform:

Besides work connected with camp administration, installation or maintenance, prisoners of war may be compelled to do only such work as is included in the following classes:

(c) transport and handling of stores which are not military in character or purpose. ${ }^{42}$

In paragraph $b$ of the same article, the industries in which a prisoner of war may be compelled to work are enumerated as follows: "industries connected with the production or the extraction of raw materials, and manufacturing industries, with the exception of metallurgical, machinery and chemical industries; public works and building operations which have no military character or purpase." 43

Thus, only work performed in certain industries is forbidden. Prisoners of war may be compelled to work in other industries regardless of what they produce. As Colonel Levie has observed:

Apparently a prisoner of war may now be compelled to work in a factory manufacturing military uniforms or gas masks or camouflage netting, as these items are neither made by the three prohibited manufacturing industries nor is their military character or purpose material; but once manufactured, a prisoner of war may not be compelled to load them on a truck or freight car, as they probably have a military character and they certainly have a military purpose. ${ }^{44}$

40. O. Uhler, H. Coursier, F. Siordet, C. Pilloud, R. Boppe, R. Wilhelm, \& J. Schoenholzer, Commentary on IV Geneva Convention (J. Pictet ed. 1958).

41. Rapport fra de skandinaviske utvalg, 1952, anm 8-Anvendelsen av tvangsmidler ifølge sivilkonvensjonens artikkel 51 , anet ledd.

42. Third Convention, supra note 29 , at art. 50 .

43. Id. at para. b.

44. Levie, The Employment of Prisoners of War, 57 AM. J. INT'L L. 337 (1967). 
Apparently, these rules would limit the usefulness of the prisoner of war personnel of the MRT organization to the occupying party. These personnel would be able to refuse any transport and handling of stores that were military in character, as well as any MRT work that could be said to be of metallurgical or mechanical engineering character. The civilian personnel would have less occasion to be uncooperative: apart from cases of extraordinary danger, they could refuse only guard duty and the like.

\section{G. The Needs of the Army of Occupation, the Public Utility Services, and the Civil Defense}

According to article 52 of the Hague Rules, supplemented by the second paragraph of article 51 of the Civilian Convention, requisition is only permissible when it relates to "work which is necessary either for the needs of the army of occupation, or for the public utility services, or . . transportation ... of the population of the occupied country." 45

During the German occupation of Norway, the application of this stop rule was contested when it was learned that the Germans intended to requisition the tramway equipment of the city of Oslo to replace tramway equipment in German cities that had been destroyed by Allied bombing. ${ }^{46}$

The Geneva Protocol of 1977 has introduced a new stop rule in the field, which confers a kind of immunity against requisition, or diversion from proper use, upon "matériel belonging to or used by civil defence organizations," meaning equipment, supplies, and transports used by these organizations for the performance of, inter alia, evacuation, fire fighting, and emergency repair of indispensable public utilities. ${ }^{47}$ However, this immunity is not absolute: an exception is introduced in article 63, paragraph 5:

Provided that the general rule in paragraph 4 continues to be observed [meaning that there be no diversion or requisition harmful to the civilian population] the Occupying Power may requisition or divert these resources, subject to the following particular conditions:

(a) that the buildings or materiel are necessary for other needs of the civilian population; and

(b) that the requisition or diversion continues only while such necessity exists. $^{48}$

\section{H. Judicial Review}

International law relating to the rights of the occupying power vis-à-vis the inhabitants of, and the property in, the occupied territory is thus largely treaty law and lends itself well to enforcement by courts. In a way, the treaty

45. Fourth Convention, supra note 26, at art. 51 ; see Hague Rules, supra note 15, at art. 52.

46. F. CASTBERG, supra note 39 , at 205.

47. Int'l Comm. of the Red Cross, supra note 28, at Protocol 1, art. 63, para. 4.

48. Id. at para. 5 . 
law corresponds to a constitution in these extraordinary conditions. The occupying power is, of course, always tempted to use its legislative powers to obtain in a circuitous way what the rules of international law prevent it from getting directly. For example, war-risk legislation compelling insurance companies to assume the final responsibility for damages the occupying power would otherwise have to pay under the rules of requisition might be enacted. ${ }^{49}$ The need for judicial review is thus easy to see.

This discussion provides a background for the recurrent tendency of domestic courts to interfere with and sometimes set aside ordinances from the enemy commander that lie outside his competence under international law. A classic case is the Norwegian Supreme Court, which insisted upon the primacy of its powers over those of the German occupation authorities: finally, rather than accept the limited role the Germans were prepared to let the Court play, all its members resigned their offices on December 21, 1940.

But judicial review is unpopular with socialists. When the new Swedish Constitution was being drafted, great efforts were made to get rid of this institution. These efforts may not have been fully successful, but it is clear that lay assessors recruited from among sympathizers with the occupying power, who might uphold a socialist philosophy in fulfilling their judicial role, ${ }^{50}$ are not likely to be much of a protection against an overstepping of competence by the occupying power.

\section{I. "Voluntary" Service}

The stop rules found in the treaty law refer only to compulsory requisition and to compelling prisoners of war to work. To the extent that the services are offered on a voluntary basis, it is quite clear that the occupying power is fully entitled to use them. Unfortunately, the distinction between what is compulsory and what is voluntary is not always clear. An occupying power will naturally feel free to exploit the means of pressure at its disposal to get voluntary offers of goods and services. Any power occupying Swedish territory will find that these means of pressure are considerable: the Swedish high tax society is a wonderful power apparatus to inherit.

Under article 48 of the Hague Rules, the army of occupation has the right to collect "the taxes, dues, and tolls imposed for the benefit of the State."51 Furthermore, the occupying party may, pursuant to article 49, levy "other money contributions in the occupied territory ... for the needs of the army or of the administration of the territory in question." 52 According to article 51 , when levying such contributions, the occupying power shall do so "in ac-

49. Cf. F. CASTBERG, supra note 39, at 192.

50. See pp. [10-11] supra.

51. Hague Rules, supra note 15, at art. 48.

52. Id. at art. 49. 
cordance with the rules of assessment and incidence of the taxes in force" at the time. ${ }^{53}$ This places the entire Swedish tax system in the hands of the occupying power.

It may be added that in socialist countries the taxation instrument has always been used systematically to persecute and destroy obnoxious elements of society that have been suspected of forming a hard core of resistance on behalf of the bourgeois class-for instance, farmers, artisans, and shopkeepers: "Die Besteuerung der Kapitalisten ist keine Gerechtigkeitsfrage sondern eine Zweckmä $\beta$ igkeitsfrage [the taxation of capitalists is not a question of justice but one of expediency]."

Civic courage has a very limited place in the society that resulted from the Swedish development. Mr. Justice Gustaf Petrén has dealt with this matter on the basis of his experience in the Office of the Ombudsman for the Judiciary and Civil Administration. ${ }^{54}$

A major part of the body of law that concerns all of us is so made that I may receive a special reward or avoid an inconvenience if particular reasons are present. Who decides whether I have special reasons? Evidently, the decision-makers at all levels. In this way multitudes among the people become dependent upon the authorities-officials, high and low-taking a benevolent view of them.

Petrén offers a list of illustrations of such decisions, in which taxation decisions rank high. He concludes, "He who knows that he needs the authorities to be kindly disposed towards him, will be careful to avoid doing anything that may upset these highly placed persons." 55

This form of pressure-at times innocent, at times not-has become a characteristic of the high tax society. Under belligerent occupation, when many sympathizers with the occupying power are likely to be appointed or elected to posts in the administration for the purpose of aiding the occupying party, it would be unrealistic to believe that the instrument of taxation would not be used as a weapon to call forth "voluntary" offers of goods and services. This would be a weapon at least equal in importance to the more straightforward powers set out in the Hague Rules and the Red Cross Conventions as belonging to the occupying power.

\section{J. The War of Laws}

The following provision appears in the Articles of War in the Swedish Penal Code:

A person, who, when the country is at war...

4. procures for the enemy military manpower, provisions or support, or

53. Id. at art. 51 .

54. Petrén, Maktens verkningar, Göteborgs Handels-och Sjöfartstidning, May 24, 1973, at 3.

55. Id. 
5. commits any other similar treasonable act, shall, if the act is likely to result in considerable harm to the military forces of the Realm or otherwise to the defence of the Realm or to the provisioning of the public or involves considerable aid to the enemy, be sentenced....

If the act referred to in the first paragraph is only to a lesser degree likely to result in harm to the defence of the Realm or the provisioning of the public, or involves a lesser aid to the enemy, than there stated, imprisonment for at most six years shall be imposed for treachery. If the act consisted of furnishing of equipment or provisions or of some other service to the enemy within an area occupied by him and if, considering the needs of the population, the offender's livelihood or other special circumstances, the act could not be regarded as inappropriate, no punishment shall be imposed. ${ }^{56}$

By this type of legislation, the smaller states in particular have attempted to limit the value of the rights conferred upon an occupying power by the Hague Rules and the Geneva Conventions. At one time the issue may have been seen as how to achieve a distribution of competence between the occupying power and the expelled power. The German army so favored this view that during the First World War the German army of occupation undertook to publish the legislation of the government-in-exile that applied to the occupied territory. Later the dominant view came to regard the Hague Rules as only limiting what the occupying power could lawfully request from the population-not limiting what the expelled power could request from the same population. During the Second World War in particular, the Norwegians went far in pressing this new view; they even punished Norwegian nurses for having treated German soldiers. On this point there is a clear retreat from such an interpretation of competence and responsibility in the Scandinavian Report. The report proclaims a consensus to the effect that "civilian hospitals, even if they are not requisitioned, are under a duty to receive and treat wounded or sick individuals or smaller groups belonging to the armed forces of the occupying power." 57 Furthermore, the Scandinavian experts are unanimously of the opinion that the right of the occupying power to punish a refusal to obey an order to work will not disappear just because the government-in-exile has forbidden its citizens to obey such an order, subject to the proviso that the order was made in accordance with international law. ${ }^{\mathbf{5 8}}$

The Swedish legislation on this matter is copied from the Norwegian. Consequently, the Norwegian experience may also be of some interest when interpreting the term "inappropriate" in chapter 22, section 1.59 The equivalent Norwegian term was interpreted very differently as the Second World War

56. 1962 Swedish Penal Code, supra note 34, at ch. 22, \& 1 (emphasis added).

57. Rapport fra de skandinaviske utvalg, 1952 anm. 19-Okkupasjonsmaktens rett til a rekvirere leger.

58. Rapport fra de skandinaviske utvalg, 1952, anm. 8-Anvendelsen tvangsmidler if $\varnothing$ lge sivilkonvensjonens artikkel 51 , annet ledd.

59. 1962 Swedish Penal Code, supra note 34 , at ch. $22, \S 1$. 
proceeded. During the early period, under the impact of the Norwegian defeat manifested in the 1940 armistice, nothing seemed to be inappropriate. Parliament could even be lawfully convened for the purpose of dethroning the King. During a middle period, that was no longer possible: those who agreed to serve as judges in the Supreme Court when the offices became vacant as a result of the resignations of December 21, 1940, were subsequently punished for treachery ${ }^{60}$ During a third period, which commenced when the Communists denounced their previous cooperation with the Nazis as a result of the outbreak of the German-Russian war and turned to guerrilla activity and the like, almost any contact with the enemy became inappropriate and constituted treachery. The private citizen had to have a highly developed sensitivity to understand in time what was "inappropriate" and what was not.

\section{ConCLUSION}

When one analyzes in this way what the law of belligerent occupation means in every detail, taking account of even the most modern developments, the picture is discouraging from a Swedish point of view. The overwhelming impression is that the rules today are, to say the least, inadequate for modern state conditions-in particular, those dominated by the socialist conceptions of state and law. From a Swedish point of view it would have been highly desirable for the recent work to improve the laws of war to have elucidated some of the new problems. Regrettably, that was not done. Our hope will remain, as it always has, that there will be no war, since that would make these efforts superfluous anyway.

60. 1946 Norsk Rettstidende 1139. 